\title{
Aplikasi Pembelajaran Berbasis Mobile Untuk Tuna Aksara
}

\author{
Muhammad Irwan Padli Nasution, Septiana Dewi Andriana
}

\begin{abstract}
Learning is a process of transformation that is initially not knowing to knowing. Has developed a lot of learning strategies from simple to more complex models even complicated and required a lot of tools in its application. Literacy is a basic of knowledge for humans. They can read by improving their quality, which leads to the high intellect of a person. Especially at this time humanity has entered the information age. The phenomenon of globalization is happening now accelerating so quickly, as the impact of application of Hi-tech society (high-tech society), which causes humans followed on interaction patterns very quickly. Using Information and Communication Technology (ICT) could be developed multimedia teaching materials with the concept of learning by playing fun and implemented on a mobile based learning applications. The use of mobile devices that is easy and flexibility is very useful to support the learning process for the illiterate.
\end{abstract}

\section{Index Terms - Learning, Illiterate, Mobile Device}

Abstrak - Belajar merupakan sebuah proses transformasi yang awalnya tidak tahu menjadi tahu. Telah banyak dikembangkan berbagai macam strategi pembelajaran dari yang sederhana sampai model yang lebih kompleks bahkan rumit sehingga memerlukan banyak alat bantu dalam penerapannya. Melek huruf merupakan dasar pengetahuan bagi manusia. Dengan membaca manusia dapat meningkatkan kualitas dirinya, yang berujung pada tingginya intelektualitas seseorang. Terlebih saat ini manusia telah memasuki era informasi. Fenomena globalisasi yang terjadi saat ini mengalami akselerasi yang begitu cepat, sebagai dampak dari penerapan $\mathrm{Hi}$-tech society (masyarakat berteknologi tinggi), yang menyebabkan manusia tergiring pada pola interaksi yang sangat cepat. Menggunakan Teknologi Informasi dan Komunikasi (TIK) dapat dikembangkan bahan ajar multimedia

Manuscript received May 02, 2016. This work was supported in part by Information System Department of Universitas Islam Negeri Sumatera Utara, Medan, Indonesia

Muhammad Irwan Padli Nasution. Author is with the Information System Department of Universitas Islam Negeri Sumatera Utara, Medan, Indonesia (corresponding author email irwannst75@gmail.com)

Septiana Dewi Andriana. Author is with the Information System Department of STT Harapan Medan, Indonesia (corresponding author provide email septianad89@gmail.com) dengan konsep belajar dengan bermain yang menyenangkan dan diimplementasikan pada sebuah aplikasi pembelajaran berbasis mobile. Penggunaan perangkat mobile (mobile device) yang mudah dan fleksibilitas sangat bermanfaat untuk penunjang proses belajar mengajar bagi para tuna aksara.

Kata Kunci - Belajar, Tuna Aksara, Mobile Device

\section{PENDAHULUAN}

Berdasarkan undang-undang Republik Indonesia B nomor 20 tahun 2003 tentang Sistem Pendidikan Nasional pada pasal 6 ayat (1) berbunyi setiap warga negara yang berusia tujuh sampai dengan lima belas tahun wajib mengikuti pendidikan dasar.[8] Program pemerintah untuk wajib belajar pendidikan dasar 9 tahun, sudah dan masih berjalan. Kemudian sesuai perkembangan pemerintah berencana akan melaksanakan wajib belajar 12 tahun. Menteri Koordinator Bidang Pembangunan Manusia dan Kebudayaan Puan Maharani mengatakan, pelaksanaan program wajib belajar 12 tahun dimulai pada Juni 2015. Pada hakekatnya pemerintah terus berupaya meningkatkan taraf kehidupan rakyat dengan mewajibkan semua warga negara Indonesia untuk menamatkan pendidikan dasar secara merata. Tidak relevan bila dimasa modern ini masih ada anak-anak Indonesia yang tidak bersekolah apalagi masih ditemukan buta huruf. Program ini merupakan langkah pemerintah untuk mencerdaskan anak-anak Indonesia yang merupakan generasi muda penerus bangsa. Karena nantinya kemajuan dan perkembangan bangsa Indonesia ada di tangan para generasi muda yang mempunyai rasa nasionalisme tinggi yang akan membuat negara Indonesia tercinta ini akan menjadi lebih baik lagi dari sebelumnya. Selain itu dengan adanya program pendidikan ini, pemerintah berharap nantinya anak-anak Indonesia tidak akan ketinggalan dengan berbagai informasi, ilmu pengetahuan, teknologi dan seni (IPTEKS) yang semakin berkembang dan mengalami kemajuan seiring dengan perkembangan zaman yang semakin modern dan global. Dalam pemanfaatan TIK untuk memperbaiki mutu pembelajaran, ada tiga hal yang harus diwujudkan, yaitu: (1). Peserta didik dan pendidik harus memiliki akses teknologi digital di dalam lingkungan lembaga pendidikan. (2). Adanya materi yang berkualitas dan bermanfaat bagi pendidik dan peserta didik. (3). Pendidik harus memiliki pengetahuan dan keterampilan dalam menggunakan fasilitas dan media pembelajaran digital untuk 
membantu peserta didik agar mencapai standar akademik dan mengembangkan potensinya.

Berdasarkan data Pusat Data dan Statistik Kemendikbud tahun 2015, angka buta aksara di Indonesia masih tergolong tinggi. Yaitu mencapai 5.984.075 orang yang tersebar di enam provinsi. Enam provinsi ini meliputi Jawa Timur 1.258.184 orang, Jawa Tengah 943.683 orang, Jawa Barat 604.683 orang, Papua 584.441 orang, Sulawesi Selatan 375.221 orang, Nusa Tenggara Barat 315.258 orang.[2] Hal ini menunjukkkan bahwa tingkat kesadaran pendidikan di Indonesia masih tergolong rendah. Apabila hal ini tidak ditanggulangi, maka Indonesia dapat menjadi negara yang terbelakang, karena sebagian besar penduduknya tidak dapat membaca.

Berdasarkan sebuah penelitian, orang-orang yang menyandang buta aksara lebih tertinggal dan lebih terbelakang daripada orang-orang yang pandai dan bisa membaca. Oleh karena itu, apabila masyarakat suatu bangsa makin tertinggal dari bangsa lain, maka bisa dikatakan pembangunan negara tersebut juga masih tertinggal dari negara lain. Upaya penanggulangan kemungkinan buta huruf dapat dilakukan sejak dini sehingga tidak menambah daftar panjang permasalahan di Indonesia melalui penambahan angka penyandang buta aksara.

Banyak fakta menunjukkan bahwa peserta didik lebih termotivasi untuk belajar dengan metode belajar yang menggunakan fasilitas multimedia daripada metode belajar konvensional. Terkait dengan meningkatnya jumlah pengguna perangkat bergerak (mobile devices) yang banyak di Indonesia, media pembelajaran berbasis mobile dapat dijadikan sebagai suatu alternatif untuk memecahkan permasalahan pada dunia pendidikan.

\section{HCI (HUMAN COMPUTER INTERACTION)}

Interaksi manusia dan komputer (human computer interaction) adalah sebuah bidang ilmu yang mempelajari desain, evaluasi, implementasi dari sistem komputer yang interaktif untuk dipakai oleh manusia serta bidang studi tentang faktor-faktor utama lingkungan interaksinya. Interaksi yang dimaksud disini adalah komunikasi dua arah antara manusia dan komputer sehingga tercipta sebuah tujuan tertentu yang ingin dicapai, melalui sebuah jembatan yaitu antarmuka. Konsep interaksi manusia dan komputer (IMK) terdiri dari tiga komponen, yaitu :

a. Manusia (The Human), manusia merupakan komponen paling penting didalam proses interaksi manusia dan komputer. Manusia berfungsi sebagai subjek sekaligus sebagai objek yang dipandang sebagai sistem pemroses informasi.

b. Komputer (The Computer), komputer adalah komponen yang bertindak sebagai pelayan manusia dalam hubungannya dengan interaksi manusia dan komputer. Komputer bertindak sebagai partisipan yang berfungsi menjalankan program dalam proses interaksi. Proses interaksi yang terjadi disini dapat dikategorikan menjadi dua hal yaitu : Interaksi Batch dan Interaksi Interaktif. c. Interaksi (The Interaction), interaksi merupakan komunikasi antara manusia sebagai pengguna dengan komputer sebagai sistem. [3]

\section{DELAPAN ATURAN EMAS (EIGHT GOLDEN RULES)}

Ada beberapa aturan mendasar untuk membuat sebuah antarmuka yang baik bagi pengguna. Menurut Shneiderman (2010), aturan mendasar tersebut dikategorikan menjadi delapan aturan atau yang sering disebut dengan delapan aturan emas, yaitu : [1][7]

a. Mempertahankan Konsistensi (Strive For Consistency), ada begitu banyak bentuk konsistensi, seperti misalnya runtutan konsistensi dari tindakan yang diperlukan dalam situasi yang sama, promt yang digunakan harus identik terminologinya, konsistensi desain pada menu, layar, dan warna, atau konsistensi pada tata letak layout, font dan lain sebagainya. Aturan mempertahankan konsistensi ini merupakan aturan yang paling sering dilanggar dikarenakan terlalu banyaknya aturan konsisten yang harus benarbenar diperhatikan.

b. Memenuhi Kegunaan Yang Umum (Enable Frequent Users To Use Shortcuts), pada aturan ini yang diperhatikan adalah bagaimana mengenali kebutuhan pengguna yang beragam jenisnya. Kebutuhan pengguna yang beragam tersebut kemudian diklasifikasikan dengan kegunaan umum, seperti misalnya pengklasifikasian pengguna pemula dan ahli, usia, kebutuhan pengguna khusus (cacat) dan lain sebagainya.

c. Memberikan Umpan Balik Yang Informatif (Offer Informative Feedback), aturan ini mengharuskan antarmuka yang baik dapat memberikan umpan balik yang informatif, dimana setiap kali pengguna melakukan tindakan kepada antarmuka, antarmuka tersebut harus langsung memberikan umpan balik kepada pengguna. Aturan ini juga mengharuskan antarmuka yang diciptakan harus dapat mempresentasikan visual dari objek yang menarik sehingga dapat membuat pengguna nyaman dalam berinterkasi dengan antarmuka tersebut.

d. Merancang Dialog Penutup (Design Dialogue To Yield Closure), pada aturan ini antarmuka yang dirancang harus memiliki urutan tindakan, seperti misalnya bagian awal (dapat berupa splash screen atau petunjuk penggunaan), bagian tengah (isi antarmuka) dan bagian akhir.

e. Memberikan Penanganan Kesalahan Yang Sederhana (Prevent Errors), aturan ini mengharuskan antarmuka yang dirancang bisa meminimalisir kesalahan yang mungkin dilakukan oleh pengguna, sehingga pengguna tidak melakukan tindkaan kesalahan yang besar, seperti misalnya item dari menu grayout yang mungkin tidak tepat dan tidak dapat mengakses karakter abjad dientri pada bidang numerik. Antarmuka harus bisa mendeteksi kesalahan dan memberikan intruksi sederhana jika pengguna melakukan kesalahan. Seperti misalnya, pengguna tidak perlu mengetikkan ulang bentuk nama atau alamat 
secara keseluruhan jika pengguna meng-input kode pos yang tidak valid, melainkan pengguna dibimbing untuk memperbaiki bagian yang salah saja.

f. Memberikan Kemudahan Untuk Kembali Ke Tindakan Sebelumnya (Permit Easy Reversal of Action), pada aturan ini antarmuka harus sebisa mungkin dirancang untuk bisa kembali pada tindakan sebelumnya, sehingga akan mengurangi tingkat kecemasan dari pengguna jika pengguna tersebut melakukan kesalahan. Pengguna yang terlanjur melakukan kesalahan dapat dengan leluasa kembali ke tindakan sebelumnya, hal ini akan memberikan efek nyaman kepada pengguna dalam berinteraksi dengan antarmuka.

g. Mendukung Pusat Kendali Internal (Support Internal Locus of Control), aturan ini ini mengharuskan operator yang berpengalaman yang bertanggungjawab atas antarmuka yang merespon tindakan mereka.

h. Mengurangi Beban Ingatan Jangka Pendek (Reduce Short-Term Memory Load), pada aturan ini layout yang dibuat harus tampil sederhana, hal ini dikarenakan manusia memiliki keterbatasan dalam pemrosesan informasi dalam memori jangka pendek (dimana aturan praktisnya manusia hanya dapat mengingat tujuh plus atau minus dua potongan dari informasi atau yang lebih dikenal dengan istilah "seven plus or minus two chunks of information").

\section{BUTA HURUF (TUNA AKSARA) DAN NELAYAN}

Menurut Kamus Besar Bahasa Indonesia (KBBI), tuna aksara adalah tidak dapat membaca dan menulis. Tuna aksara atau yang lebih dikenal dengan sebutan buta huruf adalah mereka yang tidak bisa membaca dan menulis.[9] Menurut Kamus Besar Bahasa Indonesia (KBBI), nelayan adalah orang yang mata pencaharian utamanya adalah menangkap ikan (di laut).[9] Nelayan hidup di pesisir pantai dan menggantungkan kehidupannya dengan alam. Hal ini yang menjadi salah satu faktor atau penyebab mereka mengabaikan pendidikan selain faktor kemiskinan.

\section{METODOLOGI PENELITIAN}

Metode penelitian yang dilakukan dalam penelitian ini menggunakan survey research. Survey research digunakan untuk mendapatkan data dari tempat tertentu yang alamiah (bukan buatan), tetapi peneliti melakukan perlakuan dalam pengumpulan data, misalnya dengan mengedarkan kuesioner, test, wawancara terstruktur dan sebagainya (perlakuan tidak seperti dalam eksperimen).[6] Adapun langkah-langkah dalam melakukan penelitian ini adalah sebagai berikut :

1. Merumuskan masalah penelitian dan menentukan tujuan survei, rumusan masalah dalam penelitian ini adalah bagaimana merancang desain interface pembelajaran m-learning (studi kasus nelayan tuna aksara) sesuai dengan delapan aturan emas (eight golden rules) Shneiderman and Plaisant. Tujuan survei dalam penelitian ini adalah untuk melihat interface seperti apa yang dibutuhkan atau mudah dipahami nelayan tuna aksara.

2. Menetukan konsep serta menggali kepustakaan, konsep dari penelitian ini merancang desain interface sedangkan kepustakaan dari penelitian ini bersumber dari literatur-literatur yang diambil dari penelitian-penelitian sebelumnya, jurnal-jurnal ilmiah baik dalam negeri maupun luar negeri, dan dari beberapa buku.

3. Pengambilan sampel dalam penelitian ini adalah nelayan tuna aksara yang berasal dari latar belakang pendidikan pernah bersekolah dan tidak pernah bersekolah, dengan kategori umur di bawah 15 tahun, antara 15 sampai 54 tahun, dan di atas 54 tahun yang berdomisili di Desa Ramunia I, Kecamatan Pantai Labu, Kabupaten Deli Serdang. Jumlah populasi di dalam penelitian ini tidak diketahui dengan pasti sehingga dilakukan pengambilan sampel dengan cara random. Pengambilan sampel dengan cara random dilakukan dengan menggunakan teknik bola salju (snowball sampling).

4. Pembuatan kuesioner, kuesioner dalam penelitian ini diisi bukan oleh objek penelitian (dalam hal ini nelayan tuna aksara) melainkan diisi oleh lingkungan terdekat dari objek penelitian.

5. Pekerjaan lapangan, pada langkah observasi penelitian ini dilakukan di Desa Ramuni I, Kecamatan Pantai Labu, Kabupaten Deli Serdang.

6. Pengolahan data, data yang didapatkan disusun melalui beberapa langkah, yaitu proses editing, tabulasi, dan analisis. Data yang telah di-editing disusun ke dalam bentuk tabel berdasarkan hubungan variabel sekaligus dilihat persentasenya dan kemudian dianalisis sesuai dengan kebutuhan pembahasan pada penelitian ini.

7. Analisa dan pelaporan, data yang telah dipaparkan sebelumnya kemudian dilakukan analisis dan pelaporan sehingga memperoleh sebuah informasi baru dalam bentuk klasifikasi data

\section{DESAIN ANTARMUKA APLIKASI}

Antarmuka sebuah media yang berfungsi sebagai media jembatan antara manusia sebagai pengguna dengan komputer sebagai sebuah sistem. Antarmuka dari aplikasi yang dikembangkan pada penelitian ini dapat terlihat pada Gambar 1 berikut.:

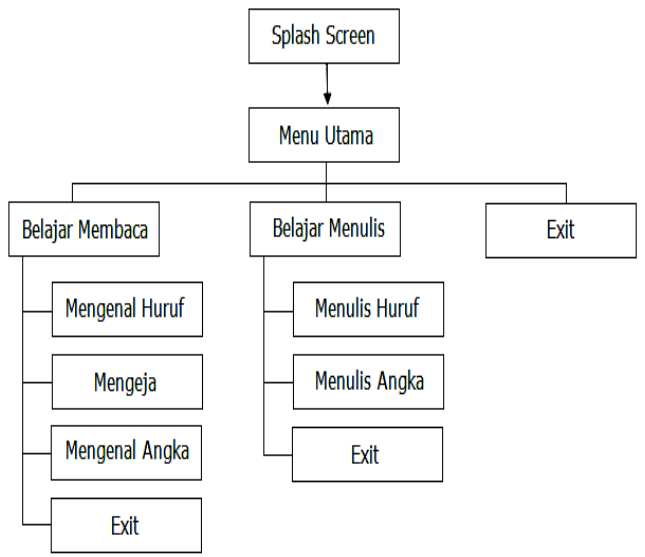

Gambar 1. Menu Utama Aplikasi Tuna Aksara 
1. Rancangan Desain Antarmuka Splash Screen

Berbicara mengenai rancangan desain antarmuka untuk pengguna tuna aksara ini, peneliti membuat desain khusus yang sebisa mungkin dapat membuat pengguna tuna aksara akan merasa nyaman dalam berinteraksi dengan antarmuka pada aplikasi yang dikembangkan. Setiap layout dilengkapi dengan gambar dan perintah suara.

Berikut gambar untuk rancangan desain antarmuka bagi pengguna tuna aksara :

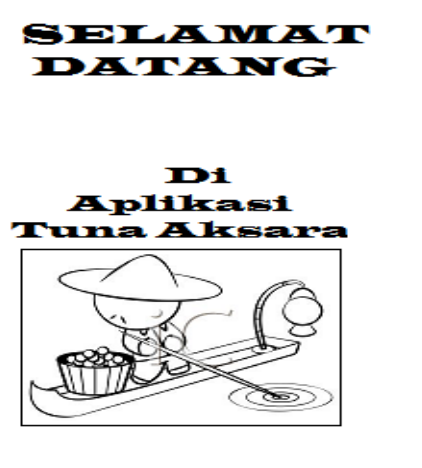

Gambar 2. Rancangan Desain Antarmuka Splash Screen

Sesuai dengan 8 aturan emas oleh Shneiderman \& Plaisant pada aturan yang kedua, yaitu memenuhi kegunaan yang umum (enable frequent users to use shortcuts), rancangan desain pada gambar di atas khusus dibuat bagi pengguna tuna aksara yang didesain untuk pengguna tingkat pemula atau novice (first time users),[1] dengan tidak terlalu banyak menampilkan icon yang dapat menimbulkan kecemasan pengguna dalam berinteraksi dengan antarmuka, karena dengan icon yang terlalu banyak dapat membuat pengguna binggung dalam berhadapan dengan antarmuka. Sesuai dengan aturan pertama dari eight golden rules Shneiderman \& Plaisant, yaitu mempertahankan konsistensi (strive for consistency),[1] disetiap layout pada antarmuka pada penelitian ini dilengkapi dengan gambar dan suara (berupa panduan yang harus dilakukan pengguna tuna aksara).

2. Rancangan Desain Antarmuka Menu Utama

Sesuai dengan eight golden rules Shneiderman \& Plaisant pada aturan yang ketiga, yaitu memberikan umpan balik yang informatif (offer informative feedback), pada menu utama ini pengguna dapat memilih menu yang ingin dilihat terlebih dahulu.

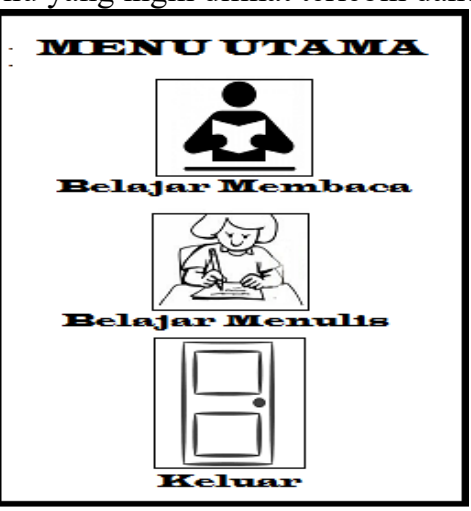

Gambar 3. Tampilan Menu Utama

Perintah suara yang menjadi panduan pengguna akan mengarahkan pengguna memilih layout yang pengguna inginkan, seperti misalnya jika pengguna ingin melihat layout belajar membaca cukup dengan menekan gambar orang sedang memegang buku, untuk melihat layout belajar menulis dapat menekan gambar orang sedang menulis, dan gambar pintu untuk menutup antarmuka. Gambar pintu untuk menutup antarmuka tersebut dibuat sesuai dengan aturan keempat Shneiderman \& Plaisant yaitu merancang dialog penutup (design dialogue to yield closure).[1]

a. Rancangan Desain Antarmuka Belajar Membaca

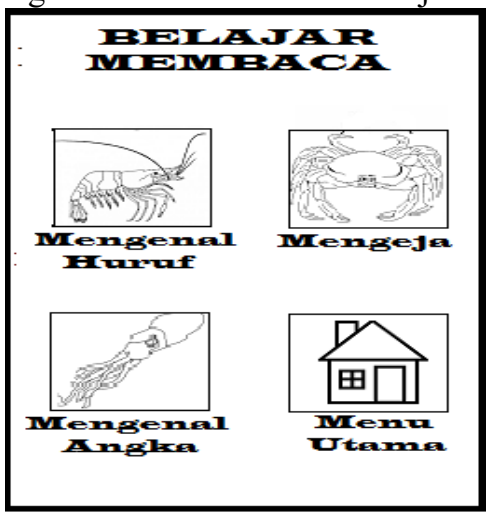

Gambar 4. Tampilan Menu Belajar Membaca

Menu belajar membaca ini terdiri dari empat pilihan sub menu, yaitu : menu mengenal huruf, menu mengeja, menu mengenal angka dan pilihan kembali ke menu utama. Pengguna dapat memilih menekan gambar udang jika ingin melihat layout mengenal huruf, pengguna juga dapat menekan gambar kepiting untuk melihat layout mengeja, pengguna juga bisa milih gambar cumi-cumi untuk melihat layout mengenal angka dan terakhir untuk kembali ke menu utama pengguna dapat menekan gambar rumah. Sesuai dengan eight golden rules dari Shneiderman \& Plaisant pada aturan ke enam yaitu : memberikan kemudahan untuk kembali ke tindakan sebelumnya (permit easy reversal of action), [1] pada menu belajar membaca ini pengguna dapat dengan mudah kembali ke menu utama dengan menekan gambar rumah. Mempertahankan aturan pertama yaitu menjaga konsistensi, maka setiap pengguna tuna aksara memilih gambar rumah akan masuk ke dalam menu utama.

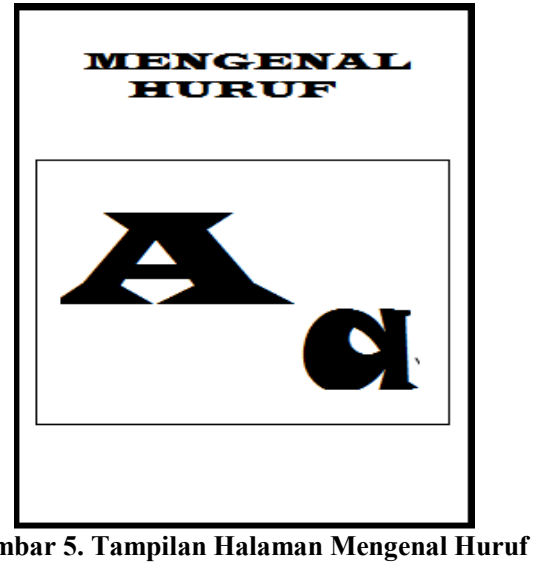

Aturan Shneiderman \& Plaisant yang dipakai pada halaman mengenal huruf ini yaitu : mengurangi beban ingatan jangka pendek (reduce short-term memory load).[1] Aturan ini menjelaskan jika manusia memiliki keterbatasan dalam memproses informasi, untuk itu dalam perpindahan layout huruf a sampai dengan huruf $\mathrm{z}$ halaman ini menggunakan timer, sehingga pengguna 
tuna aksara cukup melihat dan mendengarkan runtutan abjad huruf a sampai huruf $\mathrm{z}$ yang akan ditampilkan oleh antarmuka.

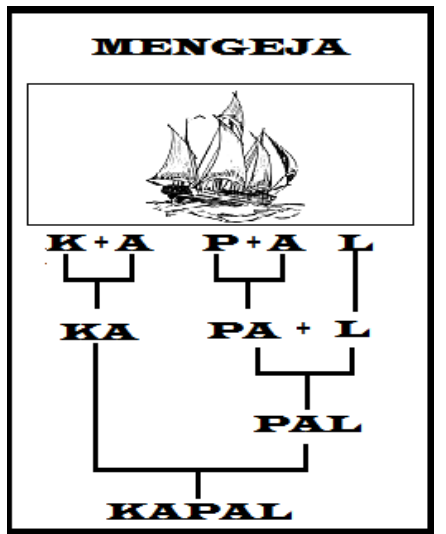

Gambar 6. Tampilan Halaman Mengeja

Halaman mengeja di atas didesain sesuai dengan aturan ketujuh Shneiderman \& Plaisant yaitu : mendukung pusat kendali internal (support internal locus of control).[1] Halaman ini mengharuskan adanya pendamping yang bertugas sebagai penanggung jawab (dalam hal ini menunjukkan huruf demi huruf hingga akhirnya terbentuk sebuah kata) dari feedback yang diberikan oleh antarmuka. Feedback yang diberikan oleh antarmuka berupa ejaan suara, huruf demi huruf hingga membentuk sebuah kata.

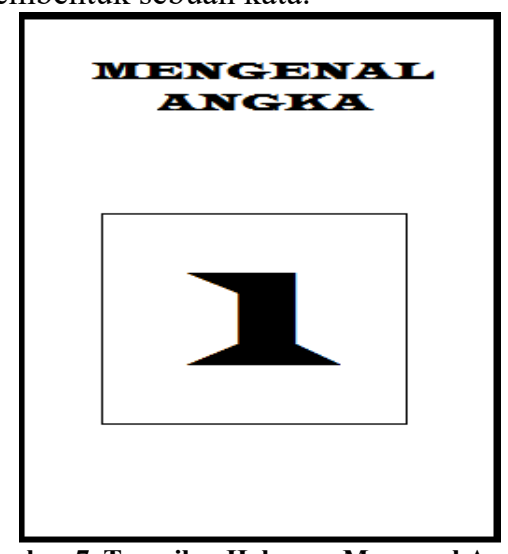

Gambar 7. Tampilan Halaman Mengenal Angka

Pada halaman ini juga digunakan timer sebagai media untuk memindahkan layout angka 1 sampai dengan 9. Hal ini dirancang sesuai dengan aturan ke lima Shneiderman \& Plaisant, yaitu : memberikan penanganan kesalahan yang sederhana (prevent error). Kesalahan sederhana yang sering dilakukan oleh pengguna tuna aksara (dalam hal ini pengguna tuna aksara masuk ke dalam kategori tingkat pemula atau novice) adalah dalam memberikan umpan baik ke dalam antarmuka, seperti misalnya salah dalam menekan tombol atau gambar. Menanggulangi kesalahan ini, antarmuka pada penelitian ini sengaja di desain dengan timer agar tidak ada urutan abjad atau angka yang terlewatkan dan pengguna tuna aksara tidak harus melakukan umpan balik ke dalam antarmuka (dalam hal memindahkan layout ke layout berikutnya), dan cukup hanya memperhatikan saja.

b. Rancangan Desain Antarmuka Belajar Menulis

Desain menu belajar menulis ini terdiri dari tiga pilihan sub menu yaitu : menu menulis huruf, menu menulis angka dan pilihan untuk kembali ke menu utama.Sesuai dengan aturan pertama dari Sheiderman yaitu menjaga konsistensi, untuk kembali ke menu utama antarmuka akan selalu diwakilkan dengan gambar rumah.

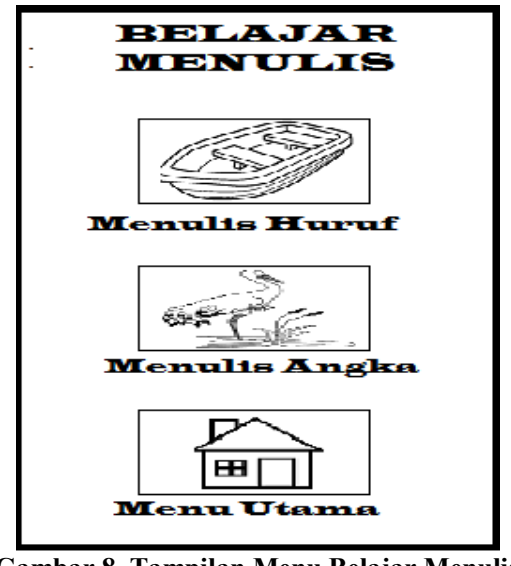

Gambar 8. Tampilan Menu Belajar Menulis

Pengguna dapat memilih menekan gambar sampan jika ingin melihat layout menulis huruf, pengguna juga dapat menekan gambar bangau untuk melihat layout menulis angka dan terakhir untuk kembali ke menu utama pengguna dapat menekan gambar rumah.

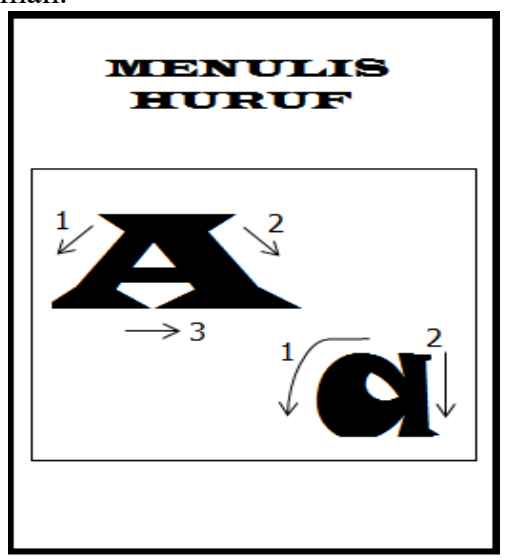

Gambar 9. Tampilan Halaman Menulis Huruf

Pengguna diminta memberikan umpan balik (feedback) ke dalam antarmuka dengan cara menuliskan huruf demi huruf berdasarkan urutan abjad di dalam alfabet. Pengguna tuna aksara dapat mengikuti arah panah yang menjadi background pada setiap halaman menulis huruf ini. Halaman ini dilengkapi dengan timer untuk memudahkan pengguna tuna aksara berpindah dari satu huruf ke huruf yang lainnya. Timer diberi jeda waktu sampai 20 detik untuk setiap hurufnya, hal ini sesuai dengan pengguna tuna aksara yang masih awam dalam berinteraksi dengan antarmuka.

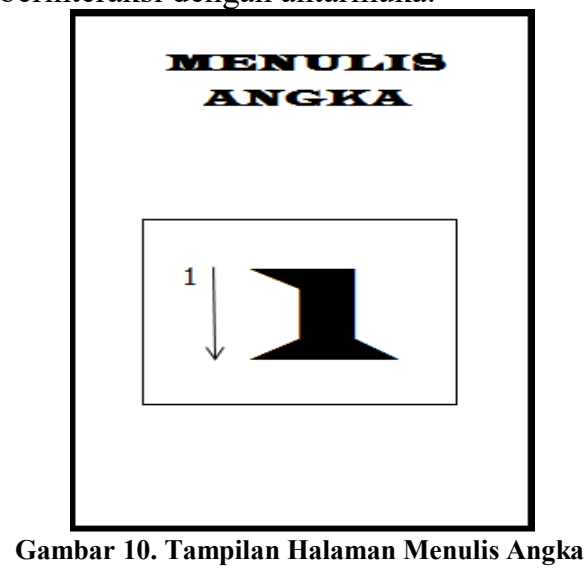


Halaman menulis angka ini juga sama seperti halaman menulis huruf diatas. Pengguna tuna aksara juga diminta memberikan feedback pada halaman ini, dan halaman ini juga dilengkapi dengan timer dan aturannya sama seperti halaman menulis huruf di atas.

\section{KESIMPULAN}

Delapan aturan emas Shneiderman and Plaisant merupakan pedoman baku yang dapat digunakan untuk merancang atau membangun antarmuka aplikasi untuk pengguna tingkat pemula atau novice (dalam hal ini pengguna tuna aksara).

Aplikasi pembelajaran ini cukup mudah untuk digunakan oleh para tuna aksara. Pengguna tuna aksara yang sebelumnya pernah bersekolah namun putus ditengah jalan lebih cepat memahami penggunaan aplikasi ini jika dibandingkan dengan pengguna tuna aksara yang tidak pernah sama sekali mengenyam pendidikan. Interaksi yang terjadi pertama kali antara pengguna tuna akasara dengan aplikasi terlihat kaku. Pengguna tuna aksara pada awalnya hanya merasa takut untuk menekan gambar pada aplikasi meskipun pengguna sudah mengerti maksud dari suara yang keluar dari aplikasi.

\section{REFERENSI}

[1] B. Shneiderman, C. Plaisant. 2010. Designing The User Interface. Addison Wesley Longman, Inc.

[2] www.bps.go.id (diakses 30 April 2016)

[3] AJ.Dix, dkk, 2003, Human Computer Interaction : Third Edition, Prentice Hall, USA

[4] Nazruddin Safaat H. 2015. Aplikasi Berbasis Android : Berbagai Implementasi Dan Pengembangan Aplikasi Mobile Berbasis Android, Edisi Revisi. Bandung. Informatika.

[5] Irawan. 2014, Aplikasi Android Dengan Eclipse, Palembang. Maxikom.

[6] Sugiyono, N, 2001, Statistik Untuk Penelitian, CV. Alfabet, Bandung

[7] M. I. P. Nasution, S. Dewi Andriana, P. Diana Syafitri, E. Rahayu and M. R. Lubis, "Mobile device interfaces illiterate," Technology, Informatics, Management, Engineering \& Environment (TIME-E), 2015 International Conference on, Samosir, 2015, pp. 117120 ,

$\underline{\mathrm{http}}$ ://ieeexplore.ieee.org/stamp/stamp.jsp?tp=\&arnumber $=738$ 9758\&isnumber $=7389729$

[8] Undang-Undang Republik Indonesia Nomor 20 Tahun 2003 Tentang Sistem Pendidikan Nasional

[9] Kamus Besar Bahasa Indonesia (KBBI) Online http://kbbi.web.id/ (diakses 30 April 2016)

I.

Muhammad Irwan Padli Nasution merupakan dosen di Universitas Islam Negeri Sumatera Utara, Medan Indonesia mengajar pada Program Studi Sistem Informasi, Program Studi Ekonomi Islam dan Pendidikan Matematika. Merupakan lulusan dari STT Harapan Medan, Universitas Sumatera Utara dan STMIK AMIKOM Yogyakarta. Sejak tahun 2006 sudah aktif menulis dan sudah banyak terpublikasi pada prosiding, jurnal nasional maupun internasional. Bidang yang diminati adalah sistem informasi, e-learning, computer for education, sistem informasi manajemen dan jaringan komputer.

Septiana Dewi Andriana merupakan dosen pada Program Studi Sistem Informasi STT Harapan Medan. Lulusan dari Magister Komputer (M.Kom) tahun 2015 dari STMIK AMIKOM Yogyakarta. Sejak tahun 2014 sudah mulai aktif meneliti bersama Bapak Muhammad Irwan Padli Nasution dan menghasilkan paper yang telah terpublikasi pada media nasional maupun internasional. 